\title{
IMPLEMENTASI SISTEM UJIAN BERBASIS KOMPUTER DI SMP NEGERI 1 SUNGAILIAT
}

\author{
Riki Afriansyah ${ }^{1}$, Muhammad Setya Pratama ${ }^{2}$ \\ 1,2 Jurusan Teknik Elektro dan Informatika \\ Politeknik Manufaktur Negeri Bangka Belitung \\ Kawasan Industri Airkantung, Sungailiat, Bangka, 33211 \\ Email: ${ }^{1}$ riki.afrian@gmail.com
}

Received: Juni 2020; Accepted : Juni 2020; Published : Juli 2020

\begin{abstract}
Abstrak
Implementasi sistem ujian berbasis komputer ini bertujuan untuk membantu SMP Negeri 1 Sungailiat dalam mengelola sistem ujian agar lebih efektif dan efisien. Pelaksaanaan sistem ujian ini dapat diakses secara bersamaan menggunakan komputer di laboratorium komputer sekolah maupun secara individu dengan menggunakan komputer atau ponsel yang terhubung dengan jaringan internet oleh siswa. SMP Negeri 1 Sungailiat masih menggunakan ujian secara konvensional sehingga hal ini tidak efektif dan efisien dari sisi biaya dan waktu. Dari sisi biaya, pihak sekolah harus mencetak soal ujian dan lembar jawaban. Dari sisi waktu, guru harus mengoreksi jawaban. Manfaat lainnya keterampilan guru meningkat dalam hal pembuatan soal berbasis teknologi. Hasil ujian secara langsung dapat dilihat oleh siswa dan pihak sekolah pada saat ujian telah selesai dikerjakan oleh siswa. Program pengabadian ini memberikan manfaat bagi sekolah dalam menilai pengetahuan siswa terhadap materi pelajaran yang telah diberikan melalui sistem ujian online apalagi di masa pandemi virus corona (COVID-19) saat ini. Penerapan metode autentifikasi sangat diperlukan pada sistem ujian berbasis komputer agar lebih aman dalam pengaksesan sistem.
\end{abstract}

Kata Kunci: sistem ujian berbasis komputer; peningkatan keterampilan guru; teknologi

\begin{abstract}
The implementation of the computer-based exam system aims to help SMP Negeri 1 sungailiat in managing the examination system to be more effective and efficient. Implementation of this examination system can be accessed simultaneously using computers in school computer laboratories or individually by using computers or cellphones connected to the internet network by students. SMP Negeri 1 Sungailiat still uses conventional tests so that this is not effective and efficient in terms of cost and time. In terms of cost, the school must print exam questions and answer sheets. In terms of time, the teacher must correct the answers. Another benefit of teacher skills is improved in terms of making technology-based questions. Exam results can be directly seen by students and the school when the exam has been completed done by students. This preservation program provides benefits for schools in assessing students' knowledge of subject matter that has been provided through the online examination system especially during the corona virus pandemic (COVID-19) at this time. The application of the authentication method is indispensable to the computer-based test system to be safer in accessing the system.
\end{abstract}

Keywords : computer based test system; teacher skills improvement; technology 


\section{Latar Belakang Masalah}

SMP Negeri 1 Sungailiat merupakan salah satu pendidikan jenjang tingkat menengah yang ada di Kabupaten Sungailiat Propinsi Bangka Belitung. SMP Negeri 1 Sungailiat memiliki tiga laboratorium komputer dengan jumlah komputer sebanyak tiga puluh satu unit per lab serta server untuk menyimpan data. Fasilitas komputer dan server yang ada di sekolah pemanfaatannya belum optimal. Sistem ujian harian dan kenaikan kelas serta tryout ujian nasional masih menggunakan kertas. Hal ini tidak efektif dan efisien dari sisi waktu dan biaya. Dalam satu kali periode ujian memerlukan lebih dari 5 rim kertas lembar jawaban dan biaya perbanyakan lembaran soal [1].

Penerapan sistem ujian berbasis komputer mempermudah dalam pengolahan data dan laporan hasil ujian. Sistem penilaian ujian secara otomatis dilakukan oleh sistem sehingga dalam mengoreksi ujian lebih cepat serta meminimalisir terjadinya kesalahan koreksi. Sistem informasi ujian online memberikan kemudahan didalam pelaksanaan dan pengolahan data ujian bagi siswa maupun guru [3]. Dengan menggunakan sistem ujian online meminimalisir kesalahan koreksi, dan mengurangi kecurangan ujian yang dilakukan siswa [4][5].

Sistem penilaian ujian dilakukan secara transparan dan realtime sehingga dapat meminimalkan kecurangaan pada saat ujian. Penerapan sistem ujian berbasis komputer tidak membutuhkan alur proses yang panjang, serta dapat meminimalkan angka kecurangan sehingga menjadi lebih jujur, adil, transparan dan akuntabel [6]. Ujian nasional berbasis multimedia sebagai alat bantu untuk membantu siswa-siswi Sekolah Menengah Pertama (SMP) dalam persiapan menjelang Ujian Nasional [7].

Penerapan UNBK dirasa dapat mempermudah dan siswa lebih siap untuk mengikuti ujian dibandingkan dengan mengikuti ujian nasional berbasis kertas [8]. Dengan sistem ujian berbasis komputer ini diharapkan fasilitas yang ada di sekolah SMP Negeri 1 Sungailiat dapat dimanfaatkan secara optimal serta memberi kemudahan bagi pihak sekolah dalam mengelola sistem ujian baik untuk ujian masuk sekolah, ujian harian, kenaikan kelas maupun untuk tryout ujian nasional. Sistem informasi ujian mandiri bertujuan untuk memudahkan suatu lembaga perguruan tinggi dalam menentukan calon mahasiswa yang berkualitas [9]

Keterampilan guru dalam penggunaan teknologi perlu ditingkatkan. Hal ini sesuai dengan peraturan pemerintah nomor 74 tahun 2008 bahwa guru harus menggunakan teknologi komunikasi dan informasi secara fungsional. Kegiatan pelatihan sangat bermanfaat bagi peserta dimana peserta dapat memahami cara penggunaan sistem ujian online dan membandingkan kelebihan sistem ujian online dibandingkan konvensional [10].

\section{Masalah}

Penerapan penggunaan sistem ujian berbasis komputer belum tersedia di SMP Negeri 1 Sungailiat padahal fasilitas dan peralatan komputer serta jaringan sudah memadai. Hal yang menjadi penyebabnya yaitu terbatasnya sumber daya manusia yang memahami dan mengerti teknologi informasi. Kemudian keterampilan guru dalam penggunaan teknologi yang masih kurang. Permasalahan ini diperoleh melalui wawancara dengan kepala sekola dan guru di SMP Negeri 1 Sungailiat. 


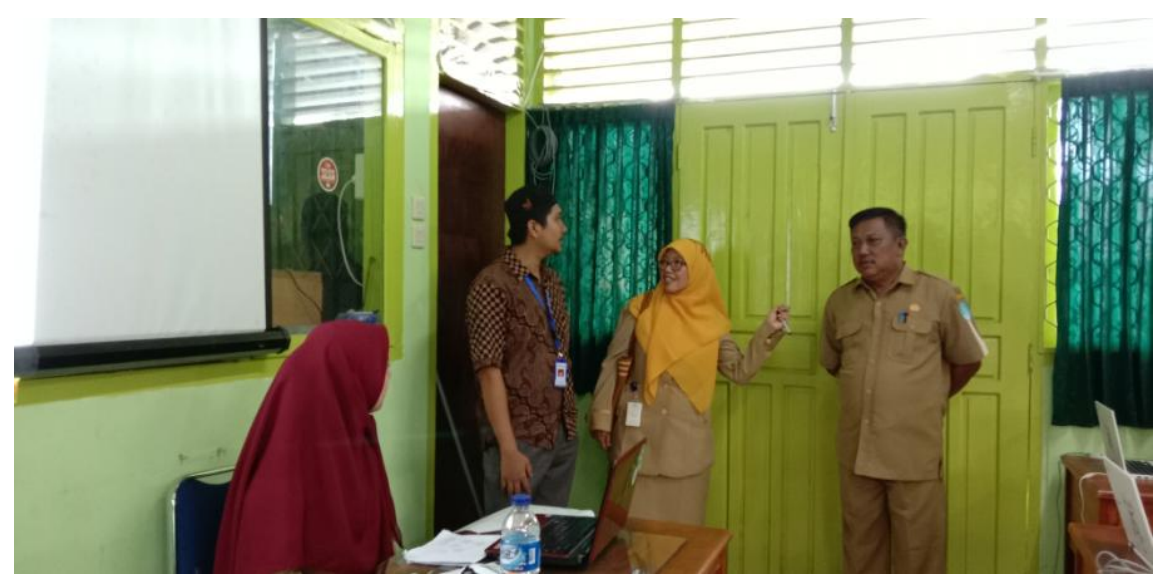

Gambar 1 Wawancara dengan pihak sekolah.

Luaran dari implementasi pengabdian masyarakat yang diberikan pada pihak sekolah sebagai berikut:

a. Tersedianya sistem ujian berbasis komputer yang dapat dikelola oleh SMP Negeri 1 Sungailiat.

b. Tersedianya modul penggunaan sistem ujian berbasis komputer.

c. Terlaksananya pelatihan dan implementasi sistem ujian berbasis komputer oleh siswa baik dilaksanakan di sekolah mapun secara online di masa pandemi virus corona (COVID-19). Perbedaan dari offline ujian terletak pada metode pengolahan datanya, jika offline diolah server local, sedangkan jika online ujian dioalah secara online [11].

Selain itu untuk keamanan sistem ujian tidak hanya menggunakan username dan password namun menggunakan token sesuai sesi waktu yang ditetapkan dan dibuat oleh operator. Keamanan menjadi salah satu aspek penting yang harus diperhatikan dalam sistem informasi ujian online oleh karena itu diperlukan metode autentikasi one time password (OTPA) [12].

\section{Metode}

Adapun metode pelaksanaan pengabdiaan sistem ujian berbasis komputer di SMP Negeri 1 Sungailiat dapat dilihat pada alir diagram di bawah ini.

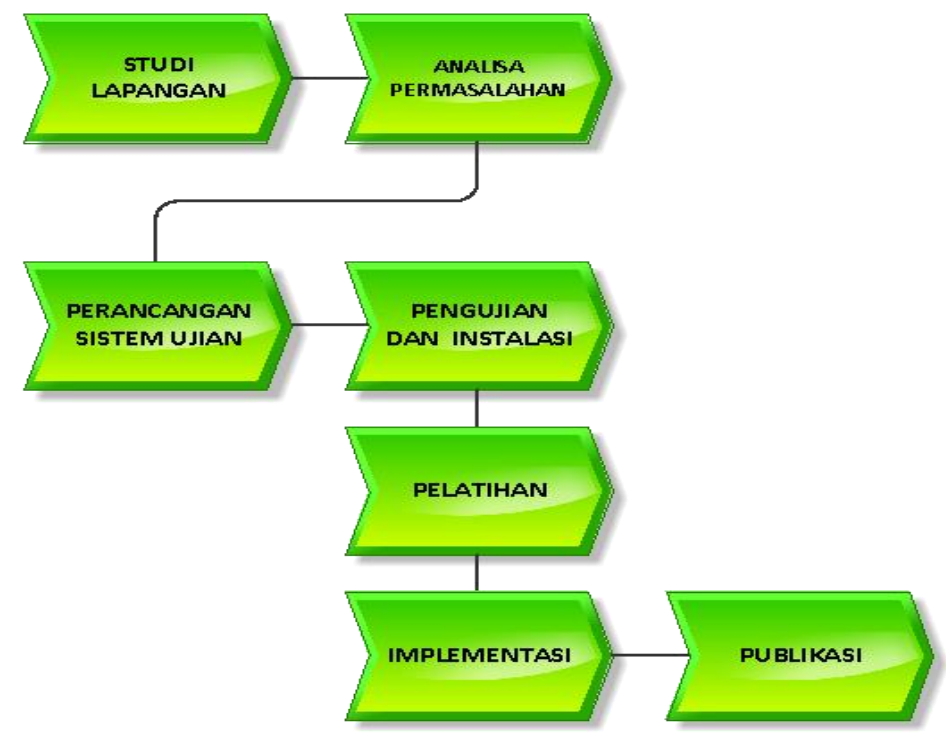

Gambar 2 Alur metode pelaksanaan. 
Adapun penjelasan dari alur di atas sebagai berikut:

a. Studi lapangan: pada tahapan ini melakukan survey dan diskusi dengan pihak sekolah dan mengidentifikasi permasalahan mengenai proses sistem ujian yang ada saat ini.

b. Analisa permasalahan: dari studi lapangan diperoleh solusi yang akan digunakan dalam pengembangan sistem ujian berbasis komputer agar pembangunan sistem sesuai dengan kebutuhan yang diharapkan.

c. Perancangan sistem: membangun sistem berbasis website dengan framework codeigniter dan database mysql.

d. Pengujian dan instalasi: setelah sistem selesai dibangun maka sistem tersebut dilakukan pengujian terlebih dahulu. Setelah itu melakukan instalasi dan konfigurasi di server sekolah.

e. Pelatihan dan implementasi: pelatihan dalam menggunakan sistem kepada guru dan operator serta melakukan implementasi ujian dengan menggunakan sistem pada mata pelajaran bahasa inggris, bahasa indonesia, matematika dan ipa.

f. Publikasi: publikasi hasil pengabdian masyarakat dalam bentuk jurnal yag akan diterbitkan pada jurnal pengabdian masyarakat.

\section{Hasil dan Pembahasan}

Adapun hasil dan pembahasan pengabdian masyarakat dalam implementasi sistem ujian berbasis komputer di SMP Negeri 1 Sungailiat sebagai berikut:

a. Studi Lapangan dan Analisa permasalahan: Melakukan observasi, wawancara dengan kepala sekolah, guru dan operator SMP Negeri 1 Sungailiat serta melakukan pengambilan data yang akan diolah untuk membangun sistem ujian berbasis komputer.

b. Perancangan Sistem: Membuat rancangan sistem informasi berdasarkan analisa kebutuhan. Ada tiga pengguna dalam sistem yaitu: admin, operator dan peserta ujian (siswa).

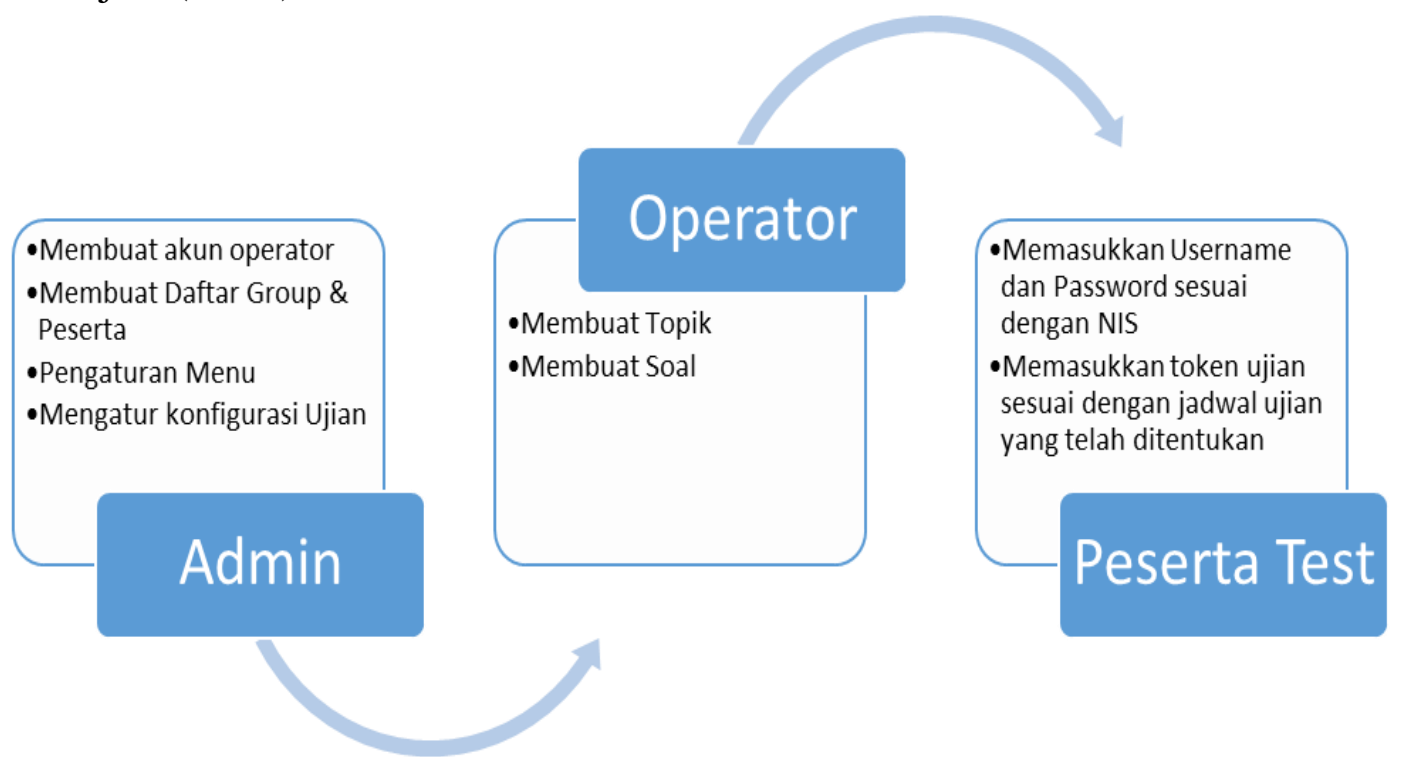

Gambar 3 Alur pengguna sistem ujian. 
Implementasi Sistem Ujian Berbasis Komputer di SMP Negeri 1 Sungailiat

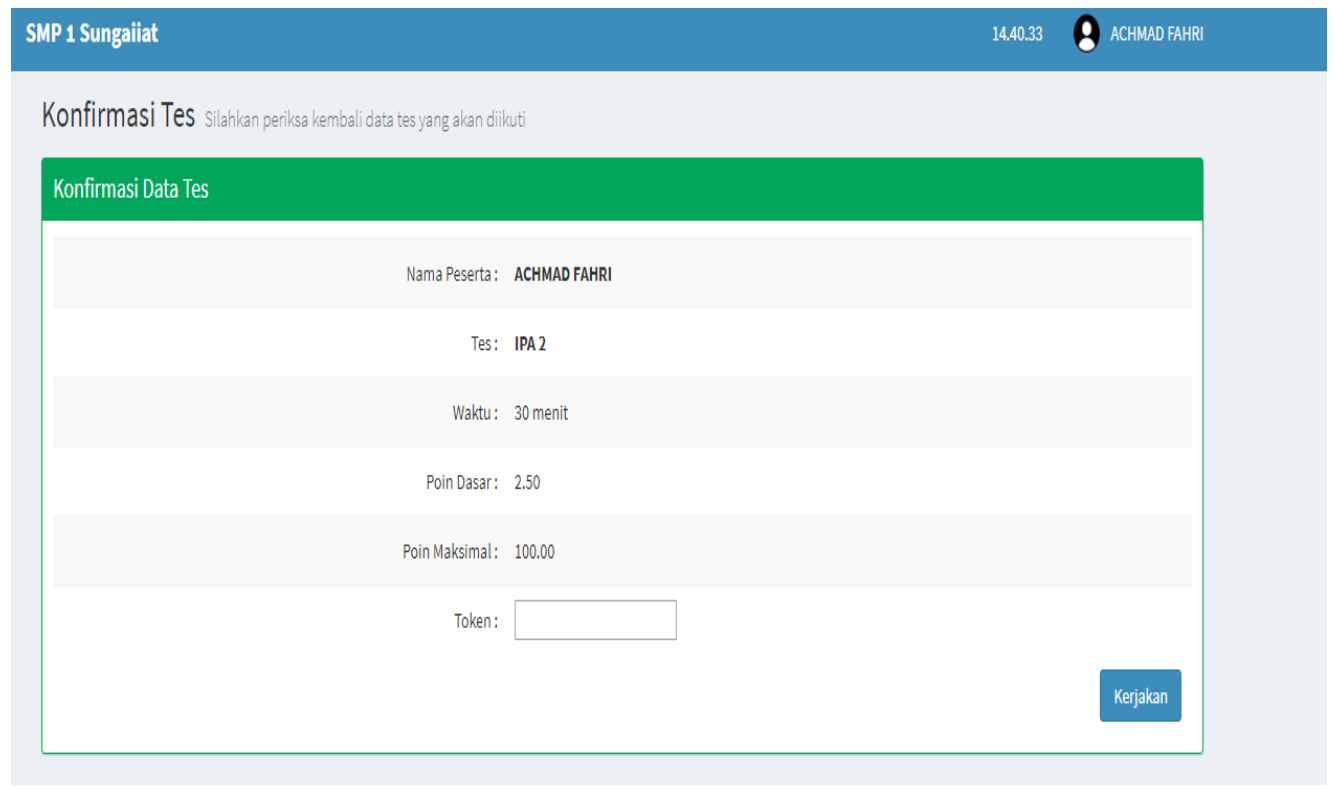

Gambar 4 Memasukkan Kode Token.

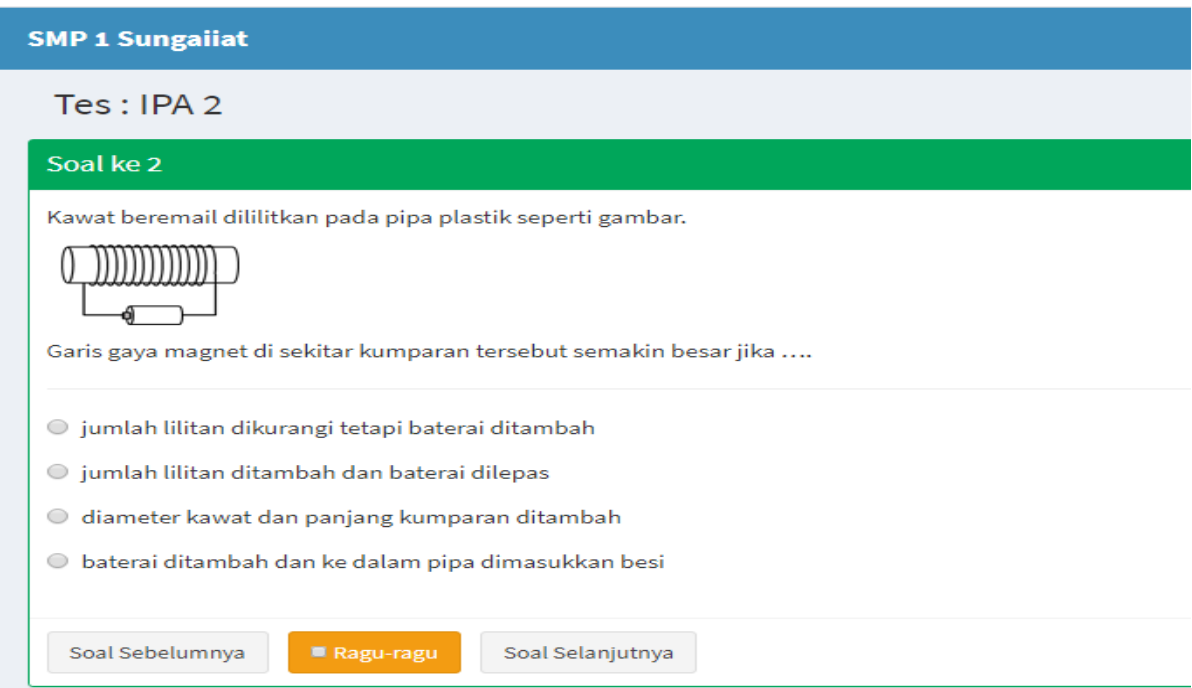

Gambar 5 Menu ujian soal oleh peserta tes (siswa).

c. Pengujian dan instalasi: pengujian pada sistem ujian berbasis komputer serta instalasi sistem yang terdiri dari database dan code program ke server sekolah.

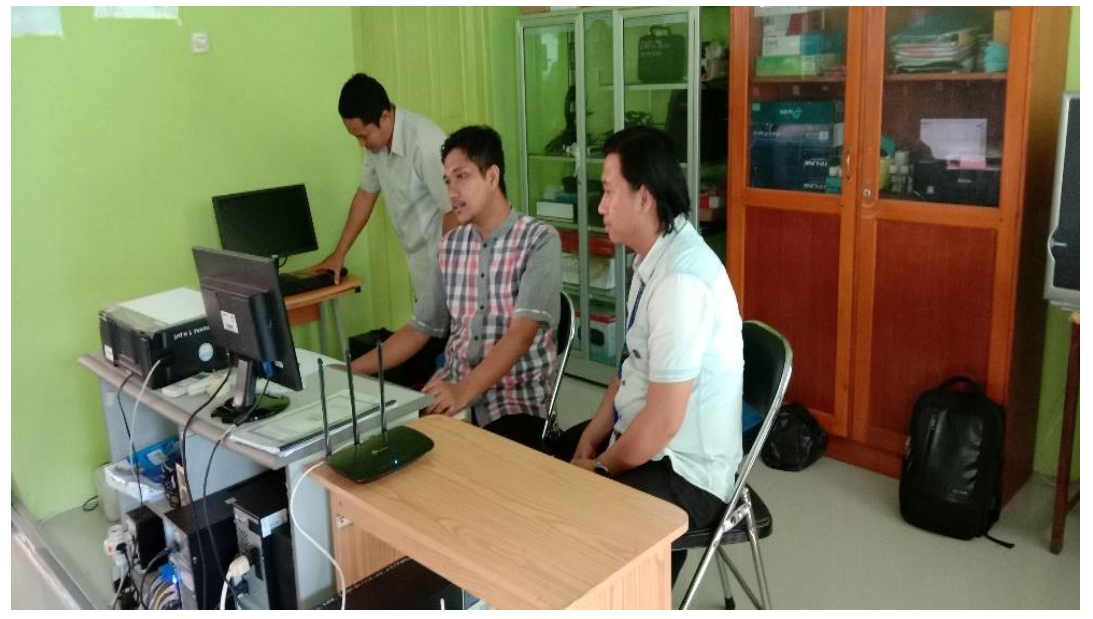

Gambar 6 Pengujian dan instalasi sistem. 
d. Pelatihan dan implementasi: setelah kegiatan instalasi selesai dilakukan maka tahapan selanjutnya melakukan pelatihan kepada operator dalam menggunakan sistem dari awal pembuatan modul soal sampai dengan pelaksanaan ujian.

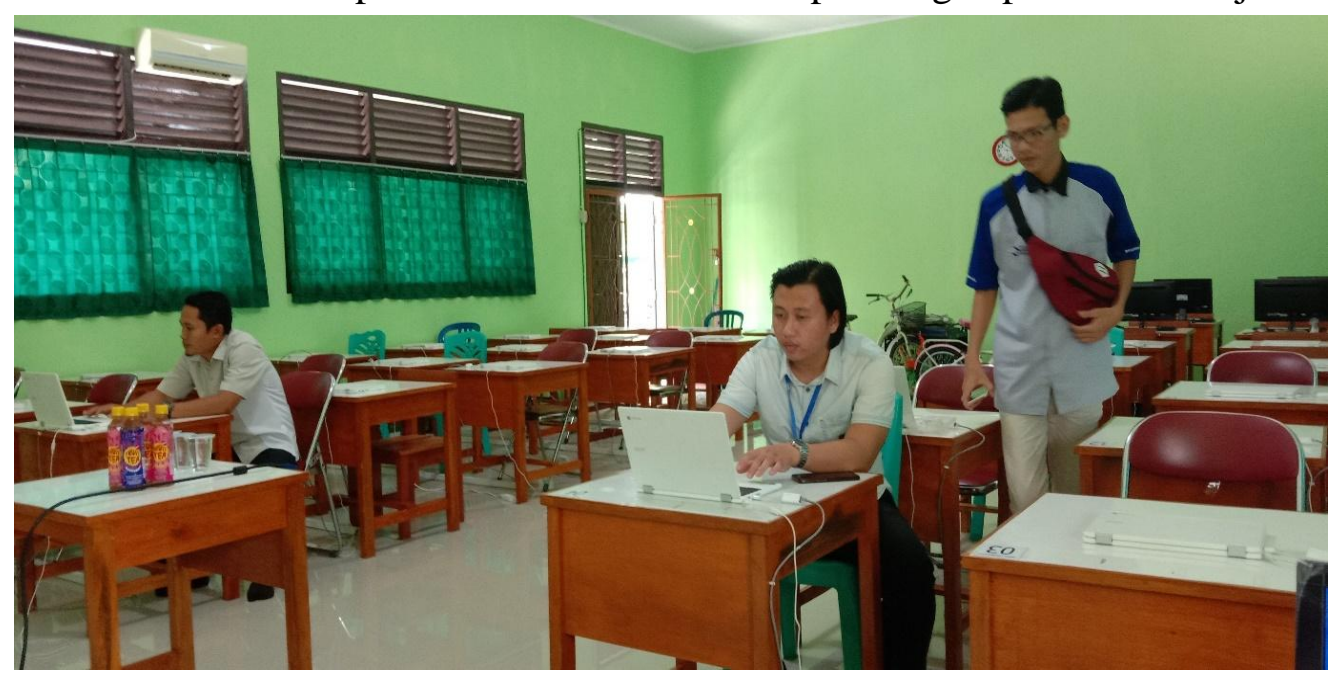

Gambar 7 Pelatihan penggunaan sistem.

Pelaksanaan implementasi sistem ujian dilakukan selama empat hari dari hari senin sampai dengan kamis menggunakan tiga laboratorium komputer. Pelaksanaan ujian perhari dibagi menjadi tiga sesi dengan jumlah peserta sebanyak 236. Serta diadakan kembali ujian ke pada siswa melalui online pada masa pandemi virus corona (COVID-19).

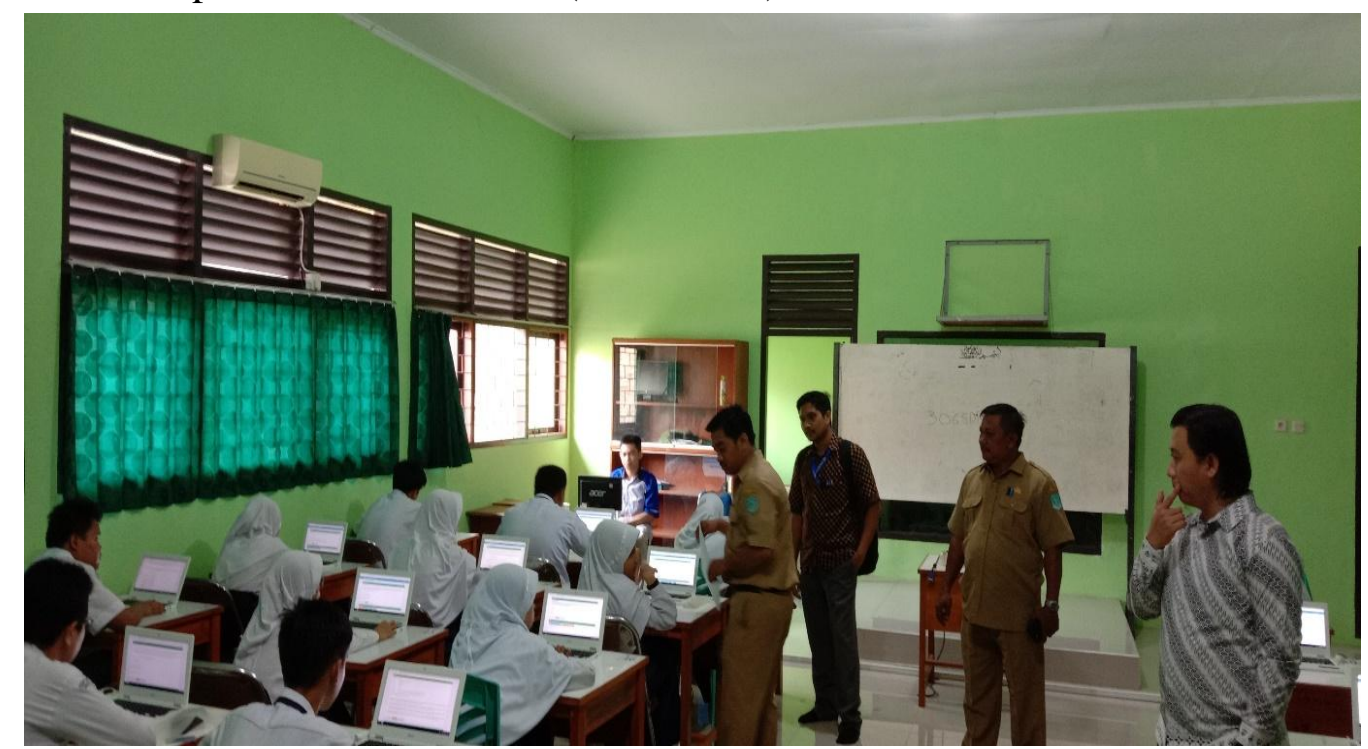

Gambar 8 Pelaksanaan sistem ujian berbasis komputer.

Hasil yang diperoleh dari pelaksanaan sistem ujian berbasis komputer selama empat hari yang dilakukan di SMP Negeri 1 Sungailiat sebagai berikut:

a. Mata pelajaran bahasa indonesia nilai tertinggi diraih oleh Muhammad Raffy Ramadhan dan Cindy Mardini dengan skor 92.

b. Mata pelajaran bahasa inggris nilai tertinggi diraih oleh Calista Putri Rheinata dengan skor 76.

c. Mata pelajaran matematika nilai tertinggi diraih oleh Sanda Yulianti dengan skor 82,5 .

d. Mata pelajaran IPA nilai tertinggi diraih oleh Donna Agustin dengan skor 70 . 
Dari hasil wawancara dengan kepala sekolah SMP Negeri 1 Sungailiat beserta enam guru yang mengelola soal ujian berbasis komputer dan satu operator pengelola sistem ujian berbasis komputer merespon program pengabdian masyarakat ini sangat membantu dan bermanfaat bagi sekolah SMP Negeri 1 Sungailiat. Adapun manfaatnya sebagai berikut:

1. Penggunaan sistem ujian berbasis komputer dapat terealisasi tahun ini serta membantu pihak sekolah dalam melakukan ujian online di karenakan adanya pandemi virus corona (COVID-19).

2. Keterampilan guru dan operator bertambah dalam penggunaan teknologi informasi.

3. Kemudahan bagi operator dalam mengelola laporan nilai serta siswa dapat melihat hasil ujian secara langsung.

4. Guru dapat mengevaluasi kemampuan siswa dari hasil pembelajaran yang telah diajarkan.

\section{Kesimpulan}

Dengan menerapkan sistem ujian berbasis komputer mempermudah dan membantu bagi sekolah SMP Negeri 1 Sungailiat dalam melakukan pelaksanaan ujian harian, ujian kenaikan, ujian masuk SMP Negeri 1 Sungailiat maupun ujian lainnya dengan menggunakan sistem informasi. selain itu manfaat dari hasil pengabdian ini meningkatkannya keterampilan guru dan operator SMP Negeri 1 Sungailiat dalam penggunaan teknologi informasi. Transparansi dan realtime hasil ujian yang diperoleh dari siswa yang telah melaksanakan ujian. Penghematan biaya kertas dalam pelaksanaan ujian serta efisien waktu dalam pengelolaan data dan laporan hasil ujian berbasis sistem informasi. Kemudahan pihak sekolah terutama guru untuk mengevaluasi hasil pembelajaran pada masa pandemi virus corona (COVID-19).

\section{Daftar Pustaka}

[1] Kamil, H., \& Pramulia, F. (2019). Pembangunan Sistem Informasi Manajemen Ujian pada Jurusan Sistem Informasi Universitas Andalas. Jurnal Nasional Teknologi dan Sistem Informasi, 5(3), 158-167.

[2] Mustamiin, M., Ismantohadi, E., Ghozali, A. L., Darsih, D., \& Inara, L. N. (2020). Rancang Bangun Sistem Manajemen Soal Dan Ujian Berbasis Website Menggunakan Framework Laravel. IKRA-ITH INFORMATIKA: Jurnal Komputer dan Informatika, 4(1), 58-63.

[3] Susilowati, S., \& Hidayat, T. (2018). Rancang Bangun Sistem Informasi Ujian Online (Studi Kasus Pada SMAN 58 Jakarta). Jurnal Teknik Komputer, 4(1), 30-36.

[4] Utami, R. D. (2019). Aplikasi Computer-Based Test Ujian pada SMP Negeri 6 Cimahi. Jurnal Teknologi dan Informasi, 9(2), 151-160.

[5] Indra, E., Sitanggang, A. L., \& Loi, M. H. (2019). Rancang Bangun Aplikasi Sistem Ujian Saringan Masuk Sma Berbasis Android (Studi Kasus SMA Amir Hamzah Medan). Jurnal Sistem Informasi dan Ilmu Komputer Prima (JUSIKOM PRIMA), 2(2), 8-16.

[6] Krispriana, A., Kumaladewi, N., \& Rahajeng, E. (2016). Sistem Informasi Computer Assisted Test (Cat) Kementerian Agama Republik Indonesia. STUDIA INFORMATIKA: JURNAL SISTEM INFORMASI, 9(2).

[7] Firmasnysah, Ada Udi. (2018). Aplikasi Simulasi Uji Coba (Tryout) Ujian Nasional Berbasis Komputer. Senar STMIK Royal, 1(1), 111-114.

[8] Santi, Mirna, \& Prajana, Andika. (2018). Analisis Implementasi Ujian Nasional Berbasis Komputer dengan Ujian Berbasis Kertas Di SMP Negeri 3 Ingin Jaya 
Kabupaten Aceh Besar. Cyberspace: Jurnal Pendidikan Teknologi Informasi, 2(2), 8491.

[9] Setiawan, T. (2019). Sistem Informasi Ujian Mandiri dan Seleksi Penerimaan Mahasiswa Baru (PMB) AMIK Garut Berbasis Intranet. Infoman's: Jurnal Ilmu-ilmu Manajemen dan Informatika, 13(2).

[10] Prasetya, W. S. (2019, December). Pemanfaatan Sistem Ujian Online pada SMP Kristen Maranatha Pontianak. In SNPMas: Seminar Nasional Pengabdian pada Masyarakat (pp. 455-461).

[11] Amin, M., \& Ramadhani, B. (2018). Implementasi Sistem Aplikasi Soal Ujian Online untuk Sekolah Menengah Pertama (SMP). SEMINASTIKA, 1(1), 91-94.

[12] Firdaus, R., Kurniawan, D., \& Simamora, E. C. (2017, March). Implementasi Metode Autentikasi One Time Password (OTPA) Berbasis Mobile Token Pada Aplikasi Ujian Online. In Prosiding Seminar Nasional Sains, MIPA, Informatika dan Aplikasi (ISBN: 978-602-98559-1-3) (Vol. 3, No. 3). 